\section{Loyalitas Kreativitas}

Aldi Masyarakat Kreatif
P-ISSN 2722-2101, E-ISSN 2722-4201

Program Studi Ekonomi Manajemen Universitas Pamulang Jurnal LOKABMAS Kreatif Vol.02,No.01,Maret 2021 Hal.84-92

Email:jurnalkreatif.manajemen@gmail.com

\title{
PELATIHAN UNTUK MENINGKATKAN PENDAPATAN WARGA DENGAN EKONOMI DIGITAL YANG KREATIF DAN INOVATIF DALAM MASA PSBB
}

\author{
Sri Retnaning Sampurnaningsih ${ }^{1}$, Fakung Rahman ${ }^{2}$, Cornelia Dumarya Manik ${ }^{3}$, \\ Achmad Ludvy ${ }^{4}, \mathrm{Nani}^{5}$ \\ ${ }^{1.2,3,4,5}$ Dosen Prodi Manajemen Fakultas Ekonomi Universitas Pamulang
}

Email : dosen01366@unpam.ac.id ; fakungrachman@yahoo.com ; Cornelia00720@unpam.ac.id ; dosen02586@unpam.ac.id ; dosen01704@unpam.ac.id

\begin{abstract}
ABSTRAK
Tujuan dari Pengabdian kepada Masyarakat (PKM) ini adalah untuk menyadarkan perilaku hidup sehat dan bersih melalui perilaku 3M (Memakai Masker, Mencuci Tangan, Menjaga Jarak), untuk memberdayakan warga yaitu ibu-ibu PKK, Bank Sampah, Posyandu dan para UMK melalui motivasi wirausaha yang kreatif dan inovatif yang berdigital, serta untuk melatih penggunaaan e-marketing guna meningkatkan pendapatan warga.Metode yang digunakan dalam PKM ini adalah penyuluhan, tanya jawab dan bimbingan kepada warga RW 14 dan RW 15 di Kelurahan Benda Baru, Pamulang. Hasil dari pelaksanaan PKM ini, diharapkan warga RW 14 dan RW 15 dapat memahami secara baik tentang pentingnya hidup sehat dan bersih serta dapat terus mengembangkan pendapatan keluarga melalui usaha yang kreatif dan berdigital dimasa PSBB ini, sehingga terbentuknya masyarakat yang mandiri dan sejahtera.
\end{abstract}

Kata kunci : wirusaha, ekonomi digital, ekonomi kreatif dan pendapatan

\begin{abstract}
The purpose of the Community Service (PKM) is to awaken healthy and clean living habits through 3M behavior (Wearing Masks, Washing Hands, Maintaining Distance), to empower residents, namely the member of PKK, Waste Banks, Posyandu and MSMEs through entrepreneurial motivation digital creative and innovative, as well as to train them the use e-marketing to increase their income. The method used in this PKM is question and answer, counseling and guidance to the residents of RW 14 and RW 15 in Benda Baru, Pamulang. The results of the implementation of this PKM are that the residents of RW 14 and RW 15 can understand good the importance of healthy and clean living, they can still continue to develop family income through creative and digital efforts in PSBB situation, so that an independent and prosperous society is formed.
\end{abstract}

Keywords: umk, digital economy, creative economy and income

\section{PENDAHULUAN}

Penyebaran virus Corona atau COVID-19 di Indonesia harus ditekan semaksimal mungkin.
Salah satu cara utamanya adalah dengan menerapkan perilaku hidup disiplin, yaitu dengan melakukan langkah $3 \mathrm{M}$ sebagai 


\section{Loyalitas Kreativitas}

\section{Aldi Masyarakat Kreatif}

P-ISSN 2722-2101, E-ISSN 2722-4201

Program Studi Ekonomi Manajemen Universitas Pamulang Jurnal LOKABMAS Kreatif Vol.02,No.01,Maret 2021 Hal.84-92

Email:jurnalkreatif.manajemen@gmail.com upaya mencegah sekaligus memutus rantai penularan COVID-19. Apa itu 3M? Membiasakan dan mewajibkan diri untuk mematuhi protokol kesehatan merupakan salah satu kunci agar virus COVID-19 dapat ditekan penyebarannya. Namun, dibutuhkan perilaku disiplin dari diri sendiri, juga sangat perlu untuk dilakukan secara kolektif dengan penuh kesadaran. Kalau kepatuhan pada protokol kesehatan, jangan lupa untuk mengingatkan kepada orang lain untuk patuh pada protokol kesehatan (Satgas PenangananCOVID19, covid19.go.id). Menerapkan 3M Demi Keselamatan Bersama berperilaku disiplin 3M adalah untuk terus menekan penyebaran virus COVID-19, dimana hendaknya diterapkan dan dibiasakan dalam kehidupan sehari-hari, terlebih di tengah situasi pandemi seperti sekarang ini. Penerapan 3M dapat dilaukan dengan menjalankan setidaknya 3 (tiga) perilaku disiplin yaitu: 1. Memakai masker, 2. Mencuci tangan dan 3. Menjaga jarak dan menghindari kerumunan Berdasarkan penelitian internasional, memakai masker kain dapat menurunkan risiko penularan COVID-19 sebesar 45 persen. Mencuci tangan dapat menurunkan risiko penularan COVID-19 sebesar 35 persen. WHO menyarankan, cucilah tangan menggunakan sabun/antiseptik selama 2030 detik dan menerapkan langkah-langkah yang benar. Jika dalam kondisi tertentu, semisal tidak ada air dan sabun atau tidak dapat menggunakan air dan sabun untuk membersihkan tangan, solusi lainnya adalah memakai cairan yang berbasis setidaknya 60 persen alkohol seperti hand sanitizer. Penerapan 3M yang paling utama adalah menjaga jarak atau social distancing dengan jarak minimal 1 meter, termasuk dengan menghindari kerumunan. jika hal tersebut dilakukan maka akan dapat meminimalisir risiko penyebaran COVID-19 hingga 85 persen. Oleh karena itu pentingnya konsistensi dan kolektif dalam melakukan perubahan perilaku menjalankan protokol kesehatan dengan disiplin dan dilakukan secara sungguh-sungguh sehingga dapat menekan angka COVID-19 di Indonesia.

Suryana (2013) berpendapat bahwa seorang wirausaha adalah mereka yang melakukan usahausaha kreatif dan inovatif dengan jalan mengembangkan ide dan meramu sumber daya untuk menemukan peluang dan perbaikan hidup. Wirausaha juga dapat didefinisikan sebagai orang yang memiliki, mengelola, dan melembagakan usahanya sendiri. Faktor yang mendorong seseorang mengambil keputusan berwirausaha dapat diketahui melalui penilaian kepribadian khususnya pengalaman dan latar belakangnya. Biografi yang dimiliki seseorang bermanfaat karena dalam biografi dapat dilihat pengalaman, keterampilan, dan kompetensi untuk peningkatan kewirausahaan, pengembangan nilai-nilai kewirausahaan dan mendorong untuk mencetuskan ide-ide kewirausahaan seseorang. Wirausaha merujuk kepada kepribadian tertentu yaitu pribadi yang mampu berdiri di atas kekuatan sendiri. sehingga mampu mengambil keputusan untuk diri sendiri, mampu menetapkan tujuan yang ingin dicapai atas dasar pertimbangannya, sehingga seorang wirausaha ini adalah seseorang yang merdeka lahir dan batin. Shefsky dalam Astamoen (2005) mendefinisikan wirausaha sebagai seseorang yang memasuki dunia bisnis apa saja, tepat pada waktunya untuk membentuk atau mengubah pusat syaraf bisnis tersebut secara substansial.

Berdasarkan pendapat para ahli, dapat disimpulkan bahwa wirausaha adalah orang yang memiliki, mengelola, melembagakan usahanya sendiri, melakukan usaha-usaha kreatif dan inovatif, mengembangkan ide dan memanage sumber daya yang ada serta memanfaatkan peluang untuk mencapai kehidupan yang lebih baik

Menurut Sukardi dalam As'ad (2002) menyatakan bahwa keberhasilan seorang wirausaha apabila ditinjau dari karakteristik psikologi mereka mempunyai profil psikologis tertentu, yaitu:

\section{a. Kepercayaan diri}

Percaya terhadap kemampuan diri sendiri untuk bekerja dengan ide kreatif, bersikap optimis dan dinamis, mempunyai kemampuan untuk menjadi pemimpin.

\section{b. Bersifat orisinil}

Merupakan kemampuan untuk menciptakan hal-hal yang baru, tidak terikat pada pola- 


\section{Loyalitas Kreativitas}

\section{Aldi Masyarakat Kreatif}

P-ISSN 2722-2101, E-ISSN 2722-4201

Program Studi Ekonomi Manajemen Universitas Pamulang Jurnal LOKABMAS Kreatif Vol.02,No.01,Maret 2021 Hal.84-92

Email:jurnalkreatif.manajemen@gmail.com pola yang sudah ada, kreatif dan cakap dalam berbagai bidang dan mempunyai pernyataan maupun pengalaman yang cukup banyak

\section{c. Berorientasi pada orang lain}

Ciri wirausahawan yang berhasil dalam tindakannya selalu menggunakan orang lain sebagai umpan balik terhadap apa yang sudah dikerjakan, baik langsung maupun tidak langsung.

\section{d. Berorientasi pada tugas}

Merupakan tingkah laku yang bertujuan menjelaskan tugas, adanya dorongan kuat untuk mengambil risiko dan menerima segala konsekuensi yang terjadi dari apa yang telah diputuskan sehubungan dengan tugasnya.

\section{e. Berorientasi pada masa depan}

Memiliki orientasi kedepan mengenai hal-hal yang terjadi dan mempengaruhi perlakuan dalam usahanya, menunjukkan kemampuan menganalisa kejadian-kejadian yang akan terjadi secara rasional berdasarkan informasi dan kegiatan pendukungnya.

\section{f. Berani mengambil resiko}

Kemampuan untuk mengambil risiko atas hal-hal yang dikerjakan. Apabila risiko yang diperoleh adalah sebuah kegagalan, maka wirausaha harus menganalisis sumber kegagalan atau hambatan dalam pencapaian tujuan dari semua usaha yang telah dikerjakannya.

Pesatnya perkembangan teknologi menuntut banyak orang untuk beradaptasi agar tak tertinggal. Hal yang sama juga berlaku untuk para umk dan mahasiswa khususnya untuk mempersiapkan bekal agar dapat bersaing di dunia kerja. Mahasiswa didorong untuk lebih kreatif, inovatif, dan jeli menangkap peluang terlebih di era digital seperti sekarang ini. Ekonomi kreatif adalah sebuah konsep di era ekonomi yang mengintensifkan informasi dan kreativitas dengan mengandalkan ide dan pengetahuan dari sumber daya manusia sebagai faktor produksi yang utama. Seiring berjalannya waktu, perkembangan ekonomi kreatif di dunia ini dihadapi dengan konsep ekonomi informasi yang mana informasi menjadi hal yang utama dalam pengembangan ekonomi.

Menurut John Howkins dalam bukunya The Creative Economy: How People Make Money from Ideas pertama kali memperkenalkan istilah ekonomi kreatif. Howkins menyadari lahirnya gelombang ekonomi baru berbasis kreativitas setelah melihat padatahun 1997, Amerika Serikat menghasilkan produkproduk Hak Kekayaan Intelektual (HKI) senilai 414 miliar dolar yang menjadikan HKI sebagai barang ekspor nomor satu di Amerika Serikat. John Howkins mendefinisikan ekonomi kreatif sebagai the creation of value as a result of idea.Dalam sebuah wawancara bersama Donna Ghelfi dari World Intellectual Property Organization (WIPO), Howkins menjelaskan ekonomi kreatif sebagai "kegiatan ekonomi dalam masyarakat yang menghabiskan sebagian besar waktunya untuk menghasilkan ide, tidak hanya melakukan hal-hal yang rutin dan berulang. Karena bagi masyarakat ini, menghasilkan ide merupakan hal yang harus dilakukan untuk kemajuan.

Ekonomi digital terus tunjukkan kemajuan seiring kemajuan teknologi di era 4.0. Di Indonesia, ekonomi digital memberi harapan besar dan diyakini menjadi penggerak mendukung transformasi dan pertumbuhan ekonomi Indonesia. Adanya loncatan kemajuan teknologi yang begitu tinggi, tiap organisasi bisnis harus memahami pemanfaatan teknologi secara tepat. Itu penting untuk menghadapi berbagai potensi disrupsi di era industri 4.0 ini.

Kunci persaingan organisasi bisnis modern kini terletak di tiga tantangan utama, yaitu

1. produk lebih baik,

1. lebih cepat dan

2. lebih murah.

Tiga tantangan itu perlu dihadapi kekuatan strategi dan pengambilan keputusan yang cepat dan tepat. Untuk bisa melakukannya, perusahaan harus lincah dalam mengolah sumber daya informasi. Pada era ekonomi digital, penggunaan teknologi sudah menjadi keniscayaan untuk meningkatkan pengelolaan data dan informasi, mendorong keunggulan kompetitif perusahaan. 


\section{Loyalitas Kreativitas}

\section{Aldi Masyarakat Kreatif}

P-ISSN 2722-2101, E-ISSN 2722-4201

Program Studi Ekonomi Manajemen Universitas Pamulang Jurnal LOKABMAS Kreatif Vol.02,No.01,Maret 2021 Hal.84-92

Email:jurnalkreatif.manajemen@gmail.com
Pendapatan dalam usaha adalah jumlah uang yang diterima oleh perusahaan atau organisasi dari kegiatan aktivitasnya seperti penjualan produk dan/atau jasa kepada pelanggan. Bagi pemerintah seperti pendapatan melalui penerimaan atau pungutan pajak. Bagi investor, pendapatan kurang penting dibanding keuntungan yang merupakan jumlah uang yang diterima setelah dikurangi pengeluaran. Pertumbuhan pendapatan merupakan indikator penting dari penerimaan pasar dari produk dan jasa perusahaan tersebut. Pertumbuhan pendapatan yang konsisten, dan juga pertumbuhan keuntungan, dianggap penting bagi perusahaan yang dijual ke publik melalui saham untuk menarik investor.

Pendapatan atau Revenue adalah pernyataan yang berhubungan dengan uang atau keuangan dari keseluruhan hasil usaha pokok produk atau jasajasa yang dilakukan oleh perusahaan dalam suatu periode. Secara sederhana revenue merupakan jumlah uang yang diterima oleh perusahaan dari hasil penjualan produk (barang atau jasa) dari pelanggan dan tidak berasal dari penanaman modal. Sedangkan penghasilan atau Income adalah jumlah uang yang didapat dari hasil penjualan dalam jangka waktu tertentu yang telah kurangi dengan harga pokok penjualan (HPP), beban dan biayabiaya lainnya. Penghasilan (Income) lebih menitik beratkan pada pengertian pendapatan bersih (net income).

\section{METODE PELAKSANAAN}

Metode kegiatan ini berupa pelatihan, tanya jawab dan bimbingan kepada warga RT 14 dan Rw 15 di Kelurahan Benda baru, Pamulang. Persiapan dilakukan segala hal yang terkait dengan materi, bahan dan alat sesuai dengan tema secara baik. Hasil persiapan tersebut dimaksudkan agar materi tersampaikan dengan mudah dimengerti serta dipahami oleh warga RT 14 dan Rw 15 di Kelurahan Benda baru, Pamulang. Berikut ini adalah tahapan pelatihan yang dilakukan

a. Memberikan pemahaman kepada para peserta PKM tentang akibat dari Pandemi Covid-19 dengan menjalankan new normal pada masa PSBB di kota Tangerang Selatan

b. Memberikan pengetahun bagaimana para Usaha Mikro Kecil dalam mengatasi masalah ekonomi pada masa pandemi ini dan memberikan motivasi wirausaha untuk mendapatkan solusi agar dapat bertahan usaha dan berkembang usaha pada masa PSBB.

c. Memberikan ketrampilan tentang apa yang dimaksud dengan digital marketing dan bagaimana realisasinya dalam menjalankan usaha melalui promosi di WA, IG dan FaceBook.

d. Mengajarkan cara membuat promosi melalui sosmed dengan menggunakan aplikasi PicArt dan Imooji.

\section{REALISASI PEMECAHAN MASALAH}

Pengabdian Kepada Masyarakat (PKM) yang dilakukan oleh dosen-dosen Prodi ManajemenFakultasEkonomi Universitas

Pamulang adalah salah satu bentuk pelaksanaan dari kegiatan Tri Darma Perguruan Tinggi. Kegiatan PKM ini dilaksanakan dengan tema Pelatihan untuk Meningkatkan Pendapatan Warga Dengan Ekonomi Digital yang kreatif dan Inovatif dimasa PSBB, bertempat di Balai RW 15 Benda Baru, pada tanggal 25 oktober 2020.

Kegiatan PKM ini berjalan dengan baik atas kerjasama dengan Lembaga Pemberdayaan Masyarakat (LPM) Benda Baru, Satgas Corvid-19 di Vila Dago Pamulang dan ketua RW 14 dan 15 di Benda Baru yang membahas tentang perlunya peningkatan pemahaman masyarakat tentang bagaimana gaya hidup dalam mencegah penyebaran virus corvid-19, dan bagaimana warga dapat melalui masa pandemi ini yang berdampak pada kehidupan social ekonomi mereka. Berdasarkan pembahasan tersebutlah maka dosen-dosen Manajemen Universitas Pamulang menyusun kebutuhan pelatihan untuk masyarakat di Benda Baru yaitu dalam bentuk pelaksanaan kegiatan Pengabadian Kepada Masyarakat (PKM), dengan dibantu oleh beberapa mahasiswa Manajemen Universitas Pamulang. Kegiatan PKM ini memberikan pelatihan kepada kurang lebih 30 warga dari RW 14 dan RW 15 di Benda Baru yang terdiri dari ibu ibu PKK, Posyandu, UMK dan anggota Bank Sampah. 


\section{Loyalitas Kreativitas}

\section{Aldi Masyarakat Kreatif}

P-ISSN 2722-2101, E-ISSN 2722-4201

Program Studi Ekonomi Manajemen Universitas Pamulang Jurnal LOKABMAS Kreatif Vol.02,No.01,Maret 2021 Hal.84-92

Email:jurnalkreatif.manajemen@gmail.com
Pentingnya pemahaman tentang hidup sehat dan bersih dalam memutus rantai penyebaran virus corvid-19, dan bagaimana menyikapi masalah yang disebabkan oleh pandemi ini dengan bijaksana. Mindset tentang bagaimana menjalankan kebiasaan baru dalam masa Pembatasan Sosial Berskala Besar (PSBB) yaitu tetap menjaga kesehatan diri dan keluarga dan menjalankan Protokol kesehatan yang ketat yaitu memakai masker, mencuci tangan dan menjaga jarak. Dan bagaimana menyikapi masalah ekonomi ditengah pandemic ini, yang kemudian menjadi tujuan dari PKM ini di Benda Baru.

Pelatihan motivasi kewirausahaan dan digitalmarketing agar tetap kreatif dan inovatif dalam menjalan usaha terutama pada masa pandemic ini dan memberikan solusi tentang pengenalan Marketing Strategi yaitu 4 P (Product, Price, Promosi, Place) dan penggunaan digital marketing melalui Sosial Media dengan menggunakan aplikasi Imooji, dan aplikasi PICSART. Marketing strategi adalah keseluruhan rencana pemasaran bisnis untuk menjangkau orang dan mengubah menjadi pelanggan untuk produk atau layanan yang disediakan. Strategi ini dalam usaha berisi antara lain cara pemasaran terbaik, informasi tentang sasaran pelanggan dan hal-hal lain yang berhubungan dengan rencana pemasaran. Berikut ini adalah beberapa langkah penting dalam menyusun strategi pemasaran kita agar strategi yang kita terapkan tersebut mencapai sasaran dan target yang kita inginkan. 1). Tentukan pelanggan yang diinginkan atau

target pasar yang ingin dicapai. 2). Kenali produk yang akan dipasarkan bagaimana produk tersebut akan memberikan manfaat dan membuat perbedaan dalam kehidupan seseorang 3). Melakukan Penelitian terhadap Persaingan. Jika ingin pelanggan tetap setia terhadap merek ataupun produk kita, maka harus menjadi yang paling menonjol atau unik di pasar yang difokuskan dari pesaing lainnya. Pertimbangkan harga, kualitas produk, lokasi, layanan dan bagaimana promosinya. 4). Penentuan sumber daya yang tersedia. Anggaran akan memastikan bahwa pemasaran atau promosi mengikuti rencana pemasaran untuk mencapai tujuan penting, memiliki gagasan yang jelas tentang anggaran yang tersedia juga akan memastikan bahwa pemasaran tidak membuat beban biaya. Tetapi uang bukan satu-satunya sumber daya yang harus dimiliki. Keterampilan yang dimiliki oleh tim pemasar (seperti menulis atau berbicara di depan umum) dan koneksi pribadi (seperti kontak di media) semuanya dapat digunakan untuk membangun strategi pemasaran. Sosial media yang diperlukan dan juga pemakaian aplikasi untuk membuat foto produk yang menarik. 5). Tentukan metode pemasaran. Setelah memahami pelanggan, pasar dan sumber daya, pilih bauran pemasaran yang paling efektif untuk mempromosikan bisnis atau produk. Bagaimana cara menunjukkan nilai produk atau layanan kepada pelanggan dan membujuk mereka untuk melakukan pembelian? Akankah melalui brosur langsung, dari mulut ke mulut, iklan online melalui social media, iklan TV atau pameran/bazaar menjadi cara yang efektif untuk menjangkau pelanggan? Setelah menentukan strategi pemasaran, kita dapat menggunakan informasi itu untuk membuat rencana pemasaran yang efektif yang akan menarik pelanggan yang tepat, membedakan produk kita dari pesaing, memposisikan bisnis kita sebagai solusi yang ideal dan memungkinkan kita untuk tumbuh di dalam pasar atau market kita.

Digital marketing adalah pemasaran produk maupun jasa yang dilakukan dengan media digital. Tujuan dari pemasaran ini adalah untuk menjangkau sebanyak-banyaknya target customer secara efisien, personal dan relevan. Pemasaran digital ini memadukan teknik serta pengetahuan dalam psikologi pasar dan teknologi.Tidak seperti pemasaran tradisional yang memasang iklan lewat baliho, pemasaran digital ini menggunakan berbagai platform digital sebagai media pemasarannya. Penggunaan media sosial di Indonesia menduduki peringkat tertinggi kelima dunia, dengan waktu penggunaan media sosial selama 3 jam 26 menit setiap harinya dimana Youtube, Whatsapp, Facebook, dan Instagram merupakan platform media sosial yang paling banyak 


\section{Loyalitas Kreativitas}

\section{Aldi Masyarakat Kreatif}

P-ISSN 2722-2101, E-ISSN 2722-4201

Program Studi Ekonomi Manajemen Universitas Pamulang Jurnal LOKABMAS Kreatif Vol.02,No.01,Maret 2021 Hal.84-92

Email:jurnalkreatif.manajemen@gmail.com diakses oleh pengguna internat di Indonesia. Oleh karena itu, banyak pelaku usaha secara agresif memanfaatkan platform digital sebagai kanal pemasaran produknya.

\section{Khalayak Sasaran}

Peserta pelatihan ada sekitar 30 orang, warga RW14 dan RW 15 Benda Baru, Pamulang.

\section{Tempat dan Waktu}

Tempat Kegiatan di Balai RW 15 Benda Baru, Pamulang. Tangerang Selatan.

Waktu Pelaksanaa: Tanggal: 23 - 25 Oktober 2020. Waktu: 08:00- 14:00 WIB

\section{Metode Kegiatan}

Metode kegiatan yang digunakan dalam pelatihan ini yaitu berupa penyuluhan, diskusi, bimbingan dan praktek penggunaan aplikasi. Kemudian para peserta diberikan post test pada akhir kegiatan untuk diisi tentang manfaat dari kegiatan ini. Adapun tahapan-tahapan yang dilakukan dalam Pengabdian Kepada Masyarakat ini diantaranya sebagai berikut:

1. Tahap Persiapan:

a. Survey Awal

Wawancara dan diskusi awal dilakukan pada tanggal 3 Juni 2010 kepada Ketua LPM Benda Baru, Pamulang, yang mana daerah pengawasannya meliputi 24 rukun warga dan 157 rukun tetangga di Kelurahan Benda Baru. Kemudian bersamaan waktunya diskusi juga dilakukan dengan organisasi masyarakat yaitu Team Siaga Covid Vila Dago Pamulang yang juga Ketua RW 20 di Benda Baru beserta pengurusnya.

\section{b. Pemantapan dan penentuan lokasi dan sasaran.}

Setelah survey dilakukan maka ditentukan lokasi pelaksanaan dan sasaran yang benar-benar membutuhkan bantuan. Adapun data yang didapatkan dari beberapa daerah di kelurahan Benda Baru, Kecamatan Pamulang, Tangerang Selatan yang perlu mendapatkan pelatihan pertama yaitu RW 14 dan RW 15. Dan diundang beberapa warga dari RW tersebut. Lokasi akan diadakan di Sekretariat LPM Benda Baru atau di Balai RW yang terlibat.

c. Alat bantu
Dalam melaksanakan PKM ini, alat bantu yang disiapkan adalah: PPP materi pelatihan sesuai kebutuhan, spanduk PKM, lap top, infocus, speaker, pointer dan screen, peralatan penunjang protocol kesehatan. Jika diperlukan akan diadakan penyemprotan disinfektan disekeliling lokasi pelatihan.

\section{Tahap Pelaksanaan}

Tahap ini adalah memberikan penyuluhan dan pelatihan kepada warga dan juga para pelaku usaha mikro dan kecil yang tekena Dampak Covid-19 baik itu online maupun offline apabila telah diperbolehkan dalam masa PSBB ini. Menggiatkan UMK dengan mengajak mereka bergabung dalam UMKM yang ada disekitar mereka. Sehingga ada pemasukan dan pengalaman yang baru dalam mendapatkan penghasilan yang halal dan thoyib. Dalam melaksanakan pelatihan, digunakan komunikasi dua arah sehingga dapat menjawab permasalashan yang ada. Memberikan motivasi perilaku bersih dan sehat, kepribadian serta bagaimana meningkatkan pendapatan warga melalu pengunaan digital markteing.

\section{Tahap Akhir}

Pembuatan Evaluasi, Laporan pelaksanaan PKM, berita dan jurnal yang menjadi luaran dari kegiatan ini. Dan membangun jaringan kerjasama yang bersinambungan dengan LPM Benda Baru.

\section{HASIL DAN PEMBAHASAN}

Warga RW 14 dan RW 15 Benda Baru,Pamulang dalam mengikuti penyuluhan sangat bersemangat dan antusias sehingga hasil kegiatan sangat memuaskan, disamping karena belum pernah mendapatkan materi PKM tersebut secara detail dan jelas. Dalam tanya jawab, juga peserta cukup banyak yang bertanya seputar ekonomi kreatif, digital marketing dan aplikasi untuk social media dimana bermanfaat untuk para ibu ibu yang mempunyai usaha dirumah hususnya, dan warga setempat umumnya. 


\section{Loyalitas Kreativitas}

\section{Aldi Masyarakat Kreatif}

P-ISSN 2722-2101, E-ISSN 2722-4201

Program Studi Ekonomi Manajemen Universitas Pamulang Jurnal LOKABMAS Kreatif Vol.02,No.01,Maret 2021 Hal.84-92

Email:jurnalkreatif.manajemen@gmail.com
Pada tahap akhir dilakukan pengisian angket/kuesioener mengenai pemahaman ekonomi kreatif dan ekonomi digital dalam mengembangkan potensi warga RW 14 dan Rw 15 dan masyarakat umumnya, sebagai tolak ukur hasl kegiatan PKM ini bisa bermanfaat untuk masyarkat.

Kegiatan PKM ini intinya berupa penyuluhan dengan penyampaian materi tentang gaya hidup baru yang memenuhi protocol kesehatan yaitu $3 \mathrm{M}$ untuk memutus penyebaran virus covid-19. Kemudian dilanjutkan dengan pemaparan materi tentang motivasi wirausaha yang kreatif dan berdigital, yang lebih dikenal dengan ekonomi digital dengan marketing digital melalui social media. Pelatihan penggunaan aplikasi seperti PICARTs dan Imooji dengan tujuan miningkatkat pendapatan warga setempat. Evaluasi melalui angket untuk mengetahui secara optimal bagaimana warga memahami gaya hidup baru dalam masa PSBB dan bagaimana untuk meningkatkan pendapatan agar kesejahteraan warga tetap optimal.

\section{KESIMPULAN DAN SARAN \\ Kesimpulan}

Pelaksanaan kegiatan Pengabdian Kepada Masyarakat (PKM) oleh Lembaga Penelitian dan Pengabdian Masyarakat (LPPM) Universitas Pamulang yang dilaksanankan oleh dosen-dosen Program Studi Manajemen telah berjalan dengan baik dan mendapatkan sembutan hangat dari peserta pelatihan. Tempat pelaksanaan adalah di Balai RW 15 Benda Baru.

Pada intinya bahwa kegiatan PKM ini bertujuan untuk memberikan solusi dimasa PSSB, dimana hampir semua lapisan masyarakat terdampak, tidak hanya kesehatan tetapi social ekonomi juga mengalami dampak serius. Pembatasan aktivitas atau PSBB ini berpengaruh pada aktivitas bisnis yang kemudian berimbas pada pendapatan masyarakat. Dengan memberikan motivasi untuk berwirausaha dapat menjadi tambahan pendapatan atau pun dapat menjadi pendapatan utama dari keluarga. Dan pada masa ini, penerapan ekonomi digital sudah menjadi keutamaan dalam menjalan kan bisnis. Terhambatnya aktivitas perekonomian otomiatis pelaku usaha melakukan efisiensi untuk menekan biaya-biaya, melalukan kreativitas dan inovasi produknya dan melakukan pemasaran online (e-marketing). Pada kegiatan ini, pada dosen Manajemen Universitas Pamulang mengajarkan beberapa aplikasi yang dapat membantu untuk memasarkan produk secara online, yaitu aplikasi Picsart dan Imooji. Kedua aplikasi ini dapat dishare ke social media seperti Wa, Ig, Facebook, dan twitter.

Manfaat dari PKM ini menambah wawasan dan ketrampilan warga dalam menggunakan digital marketing yang dapat meningkatkan pendapatan mereka dan bertahan dalam menghadapi dampak social ekonomi dimasa pandemic ini. Selain itu menguatkan usaha kecil menengah dilingkungan mereka. Ucapan terimakasih kepada seluruh pihak yang telah mendukung kegiatan ini sehingga dapat berjalan dengan baik.

\section{Saran}

Diharapkan bahwa kegiatan ini dapat berlangsung secara berkesinambungan sehingga akan terbentuk jaringan UMKM di wilayah kelurahan Benda Baru dan dapat didampingi hingga tercipta ekonomi kreatif ekonomi digital mandiri masyarakat di masa depan. Hal ini sesuai dengan visi misi dari LPM yang kemudian dituangkan dalam bentuk Perjanjian Kerja Sama antara Universitas Pamulang dan Lembaga Pemberdayaan Masyarakat.

\section{DAFTAR PUSTAKA}

1. As'ad Moh, Psikologi Industri, Yogyakarta: Liberty, 2002

2. Astamoen Moko, Entrepreneurship dalam Perspektif Kondisi Bangsa Indonesia, Bandung: Alfabeta, 2005

3. Jurnal.id (2010). Retrieved from https://www.jurnal.id:

https://www.jurnal.id/id/blog/strategibisnis-untuk-bersaing-di-era-digital/ https://tirto.id/update-corona-29-mei2020-di-indonesia-data-pandemi-duniaterkini-fDD5 tengtang data update Corvid 19 di Indonesia dan di dunia 


\section{Loyalitas Kreativitas}

\section{Aldi Masyarakat Kreatif}

P-ISSN 2722-2101, E-ISSN 2722-4201

Program Studi Ekonomi Manajemen Universitas Pamulang Jurnal LOKABMAS Kreatif Vol.02,No.01,Maret 2021 Hal.84-92

Email:jurnalkreatif.manajemen@gmail.com
4. Keputusan Presiden Republik IndonesiaNomor 11 tahun 2020 Tentang Penetapan Kedaruratan Kesehatan Masyarakat Corona Virus Disease 2019 (Covid- 19);

5. Pasal 4 ayat (1) Undang-Undang Dasar Negara Republik Indonesia Tahun 1945;

6. Peraturan Pemerintah Republik Indonesia Nomor 21 tahun 2020 Tentang Pembatasan Sosial Berskala Besar Dalam Rangka Percepatan Penanganan Corona Virus Disease 2019 (Covid-19);

7. Peraturan Menteri Pendidikan Dan Kebudayaan Republik Indonesia Nomor 3 tahun 2020 Tentang Standar Nasional Pendidikan Tinggi;

8. Peraturan Menteri Pendidikan Dan Kebudayaan Republik Indonesia Nomor 7 Tahun 2020 Tentang Pendirian, Perubahan, Pembubaran Perguruan Tinggi Negeri, Dan Pendirian, Perubahan, Pencabutan Izin Perguruan Tinggi Swasta;

9. Peraturan Gubernur Banten no 443/kep.161.Huk/2020 tentang Pedoman PSBB

10. Peraturan Walikota No 338/Kep 163.Huk/2020 tentang Perpanjangan Ketiga pelaksanaan PSBB di Tangerang Selatan

11. Surat Keputusan Menteri Kesehatan Nomor HK.01.07 /Menkes/249/2020, tentang Penetapan Pembatasan Sosial Berskala Besar di Wilayah Provinsi BANTEN Dalam Rangka Percepatan Penanganan Corona Virus Disease 2019 (COVID 19);

12. Surat Edaran Nomor 2 Tahun 2020 tentang Pencegahan dan Penanganan COVID-19 di Lingkungan Kemendikbud;

13. Surat Edaran Nomor 3 Tahun 2020 tentang Pencegahan COVID-19 pada Satuan Pendidikan;

14. Surat Edaran dari Menteri Pendidikan dan Kebudayaan Nomor: 36962/MPK.A/HK/2020 tertanggal 17 Maret 2020 tentang Pembelajaran secara Daring dan Bekerja dari Rumah dalam rangka Pencegahan Penyebaran Corona Virus Disease (Covid-19);

15. Surat Edaran Nomor: 302/E.E2/KR/2020 tentang Masa Belajar Penyelenggaraan Pendidikan;
16. Suryana, Kewirausahaan Pedoman Praktis: Kiat dan Proses Menuju Sukses, Jakarta: Salemba Karya

17. Sri Retnaning Sampurnaningsih, Jeni Andriani, Zaharatul Akmar Bt Ahmd Zainudin, Denok Sunarsi, Sunanto, The Analysis of Entrepreneurship Character and Entrepreneurship Intention among Students, PJAEE, 17 (6) (2020)

18. UU No. 6 Tahun 2018 tentang Karantina Kesehatan (Lembaran Negara Republik Indonesia Tahun 2018 Nomor 128, Tambahan Lembaran Negara Republik Indonesia Nomor 6236);

\section{LAMPIRAN : FOTO KEGIATAN}
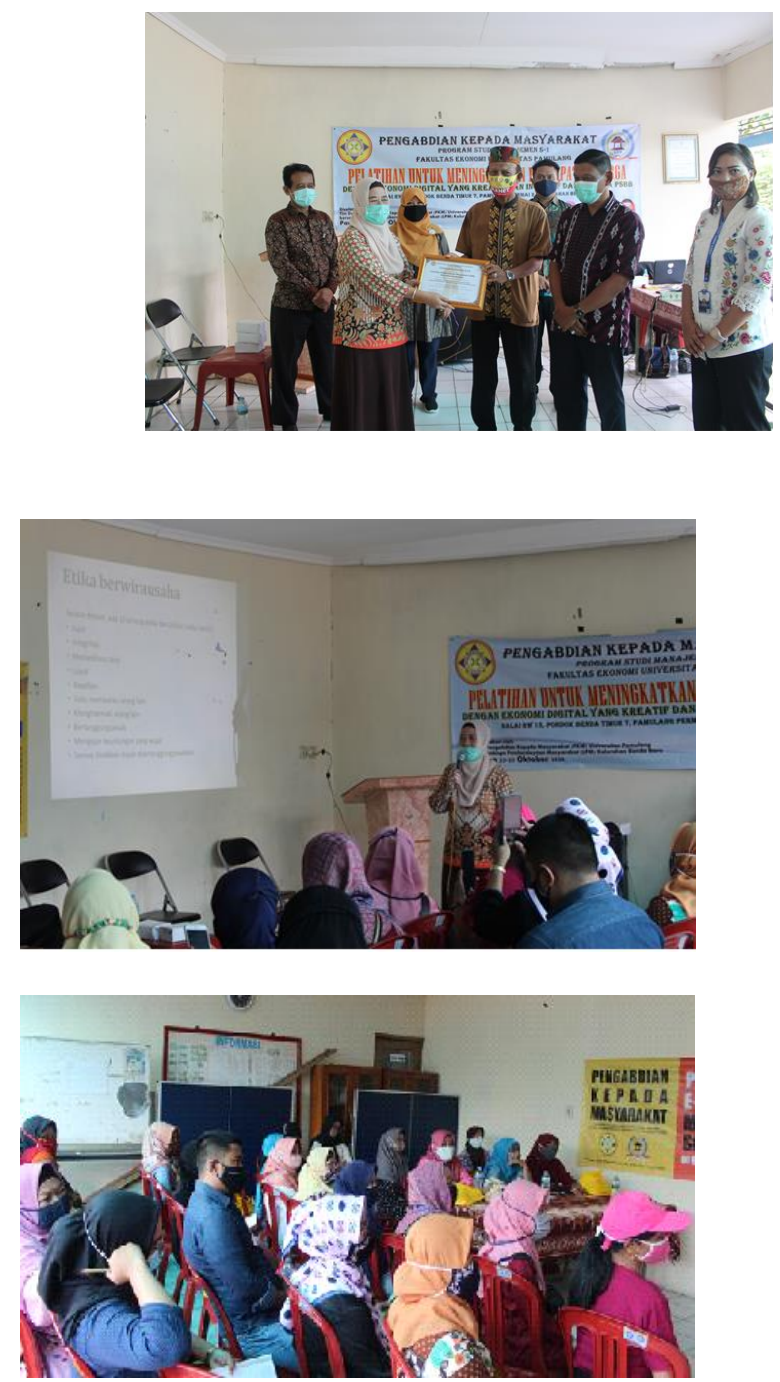
Loyalitas Kreativitas P-ISSN 2722-2101, E-ISSN 2722-4201

Program Studi Ekonomi Manajemen Universitas Pamulang

Jurnal LOKABMAS Kreatif Vol.02,No.01,Maret 2021 Hal.84-92

Aldi Masyarakat Kreatifoail:jurnalkreatif.manajemen@gmail.com 